forgotten works of a long-dead author. Throughout his life, like the Clerk of Oxenford, "of studie took he most cure and most hede", and at all times, with all people, in all circumstances, "gladly wolde he lerne and gladly teche".

C. F. BECKINGHAM.

\title{
WILLIAM GEORGE ARCHER, O.B.E., M.A., D.Litt.
}

William Archer, who died on the 6th March aged 72, will long be remembered for his major contributions to the study of both Indian tribal culture and Indian painting. After reading history at Emmanuel College, Cambridge, he aspired to a mandarin existence in Whitehall, hoping for leisure to indulge his interests in poetry and modem art. His success in the combined Home and Indian Civil Service Examinations was, however, marred by loss of marks for bad handwriting. As a result, in 1931, he found himself posted to Bihar as a member of the I.C.S.

Unexpectedly, rural India proved as vital a stimulus to his interests as life in London would have done, for already in his first year out, when on tour for tiger, he found himself far more excited by primitive images of the cattle god, Bir Kuar, than by any tiger. If these sculptures set in the remote Indian countryside reminded him of Negro, Celtic, or modern European works, the symbolic imagery of Uraon folksongs from the neighbouring Ranchi district seemed to offer a remarkable parallel to that of modern western verse. This he demonstrated in his first book, The blue grove (1940), in which sensitive translations of Uraon songs that he had collected were accompanied by a scholarly introduction on the tribal background. Meanwhile, after his marriage in 1934, he and his wife, Mildred, revisited West Bihar, where he again studied the Ahir cult and images of Bir Kuar. This resulted in his second book (1947), whose title, The vertical man, was a quotation from a poem of W. H. Auden.

After his initial period as a Sub-Divisional Officer he served as District Magistrate in Purnea and then, having spent the early years of the war as Superintendent of the Census in Bihar, he became District Magistrate of Patna in a particularly difficult period (1941/2). It was during these postings that he had opportunities for touring extensively, discovering the Picasso-like qualities of Mali and Maithil paintings as well as studying and collecting various other types of primitive art. Later, as Deputy Commissioner of the Santal Parganas (1942-5), he became an authority on Santal tribal customs and was sub. subsequently appointed as Special Officer entrusted with the task of investigaing Santal Law. During this period he also acted as editor of Man in India (1942-9). The field-work from these years with his beloved Santals bore fruit 
30 years later in his book, The hill of flutes (1974). His last appointment in India, as Additional Deputy Commissioner in the Naga Hills, again brought him into contact with tribal people with whom he felt instinctive sympathy and whose artefacts he assiduously collected.

The termination of Bill's I.C.S. career in 1948, while he was only in his early forties, set him on a new course; but the real turning point in his life perhaps dates back to those years in Patna when he paid a visit one evening to the distinguished lawyer and collector of paintings, P. C. Manuk, and also made friends with those other outstanding connoisseurs, Rai Krishna Dasa and Babu Gopi Krishna Kanoria. Manuk's miniatures were mainly from the courts of the Punjab Hills and in their grace and refinement were quite the antithesis of the types of art that Bill had hitherto admired in India. His immediate conversion to the appreciation of these miniature paintings in the company of his Indian friends sowed the seeds of his future career and when, in 1949, he was appointed Keeper of the Indian Section of the Victoria and Albert Museum, it was only natural that he should apply himself to the study of the Museum's collection of Indian paintings.

Although notable progress had been made in the study of Mughal painting prior to 1947, probably few present-day students of Indian art appreciate how little was known then about the Rajput and other provincial schools. Among the by-products of Indian independence, a flood of material released from ancestral collections was accompanied by a new impetus to Indian scholarship. On a number of study tours to India Bill renewed and extended his close friendships with Indian collectors and scholars and kept himself abreast of their latest views. Meanwhile his acquisition for the V.\& A. of the Rothenstein collection and parts of the Gayer-Anderson and J. C. French collections provided important examples of Pahari and Rajasthani paintings on which to base his research. The immediate fruit of his work on the Rothenstein collection and related material was a collection of essays, Indian painting in the Punjab Hills, published for the Museum in 1952. The problems discussed so lucidly there continued to preoccupy him but his writings over the following two decades ranged over the whole field of Indian painting and were addressed as much to the general reader as to the specialist. His books over this period included Kangra painting (1952), Bazaar paintings of Calcutta (1953), Garhwal painting (1954), Indian painting for the British (with Mildred Archer, 1955), Indian painting (1957), The loves of Krishna (1957), Indian paintings from Rajasthan (1957), Ceylon: Paintings from temple shrine and rock (with S. Paranavitana, 1958), Central Indian painting (1958), India and modern art (1959), Indian painting in Bundi and Kotah (1959), Indian miniatures (1960), Kalighat drawings (1962) and Paintings of the Sikhs (1966). He also found time to edit new editions of the Käma Sütra, Koka Sästra and Sa'dī's Gulistān and join in the translation of the Love songs of Vidyapati. 
As Keeper of the Indian Section, Bill faced up to the crisis caused by the demolition of the old India Museum building in the mid-fifties and ensured that an important part of the collections was displayed in the Victoria and Albert Museum rather than being committed to storage for an indefinite period. A glance at his bibliography will show that there was no interruption in his output during these years of major disturbance in his department. While writing on other topics he continued to wrestle with the problems of Pahari paintings and, on becoming Keeper Emeritus of the Indian Section in 1959, he commenced work on a catalogue of the Museum's important collection of Pahari miniatures. This provided him with a unique opportunity to sum up existing knowledge of the subject, but the task of meeting his own exacting standards of clarity and comprehensiveness was a daunting one, and his text went through many revisions before going to press. When the two volumes appeared in 1973 under the title Indian paintings from the Punjab Hills, the book was immediately recognised as a monumental survey of its field, indispensable today and destined to remain the basic work of reference for many years to come.

Bill Archer's entry into the field of Indian art studies happened at a time when Indian independence and the post-war booms in education, tourism and publishing brought the subject to a far wider public than in the past. That he should have played a key role in this was as much due to his infectious enthusiasm for India and its art as to his obvious ability and experience of the country. As a colleague and companion he was a constant source of inspiration, help and guidance and his warm affectionate nature and impish humour earned him a special place in the hearts of those who knew him. Public honours included the O.B.E. in 1947 and honorary doctorates from the Punjab University, Chandigarh (1968) and Guru Nanak Dev University, Amritsar (1976). He was awarded the Burton Memorial Medal by this Society last year.

ROBERT SKELTON 